Indonesian Journal of Legality of Law
e-ISSN : 2477-197X
https://postgraduate.universitasbosowa.ac.id/

\title{
ANALISIS YURIDIS TERHADAP PROSES PENYIDIKAN TINDAK PIDANA PENCURIAN YANG DILAKUKAN OLEH ANAK DI WILAYAH HUKUM KEPOLISIAN
}

\author{
Juridical Analysis Of The Investigation Process The Crime Of Theft Performed By Children In Police \\ Jurisdiction
}

\author{
Awaluddin', Marwan Mas', Abd. Haris Hamid ${ }^{2}$ \\ ${ }^{1}$ Kepolisian Daerah Provinsi Sulawesi Barat \\ ${ }^{2}$ Program Studi Ilmu Hukum Program Pascasarjana Universitas Bosowa
}

Email: axwalk19dtt@gmail.com

Diterima: 10 September 2021/Disetujui: 01 Desember 2021

\begin{abstract}
ABSTRAK
Penelitian ini bertujuan untuk mengetahui faktor penghambat dalam proses penyidikan terhadap anak yang melakukan tindak pidana pencurian di Wilayah Hukum Kepolisian Daerah Sulawesi Barat. Jenis data yang digunakan dalam penelitian ini Data primer yaitu keterangan yang diperoleh melalui wawancara secara langsung dengan informan. Wawancara dilakukan untuk memperoleh informasi yang akurat terkait dengan penegakan sanksi pidana terhadap kejahatan pencurian yang dilakukan oleh anak di Wilayah Hukum Kepolisian Daerah Sulawesi Barat yang menyebabkan terjadinya kejahatan pencurian yang dilakukan oleh anak. Dan data Sekunder yaitu data yang diperoleh melalui studi kepustakaan dengan cara membaca bukubuku, jurnal-jurnal penelitian dan karya ilmiah lainnya yang telah terdokumentasi serta data dari internet. Data sekunder juga diperoleh melalui penelusuran dokumen yang ada hubungannya dengan permasalahan penelitian ini. Penyidikan dilakukan untuk mencari serta mengumpulkan bukti-bukti yang pada tahap pertama harus dapat memberikan keyakinan, walaupun sifatnya masih sementara, kepada penuntut umum tentang apa yang sebenarnya terjadi atau tentang tindak pidana yang telah dilakukan oleh tersangka. Dan apabila berdasarkan keyakinan tersebut, penuntut umum berpendapat dan cukup alasannya untuk mengajukan tersangka ke Sidang Pengadilan jika masih mengulangi tindak pidana. Bahwa penyidikan terhadap perkara anak yang dilaksanakan oleh Penyidik Anak di Wilayah Hukum Kepolisian Daerah Sulawesi Barat dilaksanakan dalam suasana kekeluargaan. Disisi lain, dalam melakukan penyidikan anak, penyidik wajib meminta pertimbangan atau saran dari pembimbing kemasyarakatan atau jika perlu kepada ahli pendidikan, psikolog, psikiater, tokoh agama, pekerja sosial dan tenaga ahli lainnya. yang berada di Kota Mamuju. Bahwa Faktor penghambat dalam proses penyidikan terhadap anak yang melakukan tindak pidana pencurian di Wilayah Hukum Kepolisian Daerah Sulawesi Barat yaitu Sarana dan prasarana kurang memadai. Kurang penyidik yang sudah mengikuti pelatihan penyikan khusu tindak pidan yang dilakukan oleh anak. Tidak adanya tempat pemeriksaan dan penahanan umur anak. Anak belum mempunyai identitass (akta lahir, ijazah, kartu keluarga). Tempat tinggal anak tidak tetap. Sarana pendukung pada tempat kejadian pencurian kurang memadai.
\end{abstract}

Kata Kunci: Proses Penyidikan, Tindak Pidana, Pencurian, Anak

\begin{abstract}
This study aims to know the process of investigating a child who commits a crime of theft in the legal area of the West Sulawesi Regional Police. To find out the inhibiting factors in the process of investigating children who commit the crime of theft in the police jurisdiction of the West Sulawesi Region. The type of data used in this study is primary data, namely information obtained through direct interviews with informants. Interviews were conducted to obtain accurate information related to the enforcement of criminal sanctions against the crime of theft committed by children in the jurisdiction of the police in the area of West Sulawesi which led to the crime of theft committed by children. Also, secondary data was obtained through library research by reading books, research journals and other scientific work that have been documented as well as data from the internet. Secondary data was also obtained through searching documents related to the problem in this research. Investigations are carried out to seek and collect evidence which in the first stage must be able to provide confidence, although it is still temporary in nature, to the public prosecutor about what actually happened or about the criminal acts that have been committed by the suspect. Based on that belief, the public prosecutor is of the opinion and there is sufficient reason to submit the suspect to the Court Session if he is still repeating the crime. The investigation of Child Cases carried out by Child Investigators in the jurisdiction of the West Sulawesi Regional Police shall be carried out in a family atmosphere. On the other hand, in conducting investigations of children, investigators are obliged to ask for consideration or advice from community counselors or if necessary from educational experts, psychologists, psychiatrists,
\end{abstract}


religious leaders, social workers and other experts in Mamuju City. Also, the inhibiting factor in the process of investigating children who commit the crime of theft in the police jurisdiction of the West Sulawesi region is that the facilities and infrastructure are inadequate. There are not enough investigators who have attended training on special investigations of crimes committed by children. There are no investigation rooms and detention for the child. The child does not have an identity (birth certificate, diploma, family card). The place of residence of the child is not fixed. Supporting facilities at the theft scene are inadequate.

Keywords: Crime, Corruption, Judge's Decision

\section{PENDAHULUAN}

Indonesia merupakan negara hukum yang menjunjung tinggi penegakan Hak Asasi Manusia (HAM). Saat ini sering terjadi tindakan pelanggaran terhadap HAM, yang mana pelanggaran tersebut bukan hanya dilakukan oleh orang dewasa, tapi dilakukan juga oleh anak, baik sendiri maupun bersama-sama dengan berbagai macam bentuknya. memungkinan-kemungkinan yang akan menjadi kendala dalam penelitian ini, dimana tidak adanya tempat pemeriksaan dan penahanan khusus untuk anak di Wilayah Hukum Kepolisian Daerah Sulawesi Barat, namun demikian pemeriksaan terhadap anak tetap dilaksanakan dengan pertimbangan bahwa proses tindak pidana pencurian yang dilakukan oleh anak di Wilayah Hukum Kepolisian Daerah Sulawesi Barat didampingi oleh penasehat hukum yang telah ditentukan oleh penyidik atau yang ditentukan oleh yang bersangkutan. Negara mengedepankan perlindungan hak-hak anak yang menjalani proses hukum dalam setiap tahap pemeriksaan. Salah satunya adalah pembedaan proses hukum pada orang dewasa dan pada anak yang melakukan tindak pidana. Negara memberikan keringanan pada tindak pidana yang dilakukan oleh anak, karena anak sebagai generasi penerus bangsa harus diperlakukan secara manusiawi. Ditinjau dari aspek yuridis maka, pengertian anak di mata hukum positif Indonesia diartikan sebagai orang yang belum dewasa, orang di bawah umur atau keadaan di bawah umur, atau kerap juga disebut sebagai anak yang di bawah pengawasan wali. Anak merupakan anugerah yang harus dijaga, dirawat dan dilindungi. Setiap anak secara kodrat memiliki harkat, martabat dan hak-hak sebagai manusia yang harus dijunjung tinggi oleh siapapun. Dan tidak semua orang tua bisa memilikinya, anak hanya diberikan kepada keluarga yang di kehendakinya untuk mengemban amanah. Anak haruslah ditangani secara berbeda dengan orang dewasa.

Model penanganan yang berlaku melalui UU No. 11 Tahun 2012 tentang system peradilan pidana anak, adalah sama sebagaimana penanganan orang dewasa, dengan model retributive justice, yaitu pengsanksi sebagai pilihan utama atau pembalasan atas tindak pidana yang dilakukan karena alasan karakteristik anak. Alasan masa depan anak. Anak yang dipidana terlabel dan terstigmatisasi pemidanaan sehingga menyulitkan pertumbuhan psikis dan sosial anak kedepannya. Memulihkan hubungan antara Anak yang berhadapan dengan Hukum, korban dan masyaarakat. Dalam UU No. 35 Tahun 2014 Tentang Perlindungan Anak, bahwa anak adalah amanah dan karunia Tuhan Yang Maha Esa, yang dalam dirinya melekat harkat dan martabat sebagai manusia seutuhnya. Lebih lanjut dikatakan bahwa anak adalah tunas, potensi, Dan generasimuda penerus cita-cita perjuangan bangsa, memiliki peran strategis dan mempunyai ciri dan sifat khusus yang menjamin kelangsungan eksistensi bangsa dan negara pada masa depan. Oleh karena itu agar setiap anak kelak mampu memikul tanggung jawab tersebut, maka ia perlu mendapatkan kesempatan yang seluas-luasnya untuk tumbuh dan berkembang secara optimal, baik fisik, mental maupun sosial, dan berakhlak mulia. Penyimpangan yang dilakukan oleh anak disebabkan karena factor adanya dampak negatif perkembangan pembangunan yang cepat, arus globalisasi di bidang komunikasi, kemajuan ilmu pengetahuan dan teknologi serta perubahan gaya cara hidup yaitu perubahan yang mendasar yang berpengaruh terhadap nilai perilaku anak. Selain itu, anak yang kurang atau tidak memperoleh kasih sayang, asuhan, bimbingan dalam pengembangan sikap perilaku, penyesuaian dan adaptasi diri, serta pengawasan dari orang tua, wali atau orang tua asuh mudah terseret dalam arus pergaulan masyarakat yang kurang sehat dan merugikan perkembangan pribadinya. Undang-Undang Nomor 11 tahun 2012 tentang Sistem Peradilan Anak, dimaksudkan untuk melindungi dan mengayomi Anak yang berhadapan dengan Hukum.

Undang-Undang ini bermaksud agar Anak dapat menyongsong masa depannya yang masih panjang serta memberi kesempatan kepada anak agar melalui pembinaan yang diperoleh jati dirinya untuk menjadi manusia yang mandiri, bertanggung jawab, dan berguna bagi diri sendiri, keluarga, masyarakat, Bangsa, dan Negara. Sanksi bagi pelaku pencurian yang diatur dalam Pasal 363 KUHP dan Hukum Pidana Islam memiliki perbedaan yang menarik dan komphensif. Karena menurut Hukum Islam, anak dibawah umur tidaklah dikenai sanksi atau hukumman atau dalam artian tidak bisa dibebankan pertanggungjawaban atas dirinya. Permasalahan yang akan timbul selanjutnya adalah apakah kejahatan yang dilakukan oleh anak dengan latar belakang kenakalan yang disebabkan karena perkembangan sikap mental anak yang belum stabil, maka harus diperlakukan sama dengan orang dewasa, begitu pula dijelaskan dalam peraturan perundang-undangan bahwa anak tidak dapat diperlakukan sama dengan orang dewasa..

\section{METODE}

Penelitian ini menggunakan Data Primer yaitu keterangan atau fakta yang diperoleh melalui wawancara secara langsung dengan informan penelitian di Wilayah Hukum Kepolisian Daerah Sulawesi Barat. Wawancara dilakukan untuk memperoleh informasi yang akurat terkait dengan proses penyidikan tindak pidana pencurian yang dilakukan oleh anak di Wilayah Hukum Kepolisian Daerah Sulawesi Barat yang menyebabkan terjadinya kejahatan pencurian yang dilakukan oleh anak serta upaya yang telah dan akan terus dilakukan oleh pihak Kepolisian Daerah 
Sulawesi Barat dalam menanggulangi kejahatan pencurian. dan data sekunder yaitu data yang diperoleh melalui studi kepustakaan dengan cara membaca buku-buku, jurnal-jurnal penelitian dan karya ilmiah lainnya yang telah terdokumentasi serta data dari internet. Data sekunder juga diperoleh melalui penelusuran dokumen yang ada hubungannya dengan permasalahan penelitian ini. Sumber Data Penelitian dalah Bahan hukum primer yaitu bahan hukum yang mengikat yang terdiri dari peraturan perundang-undangan yang berlaku atau ketentuan-ketentuan yang berlaku yaitu Undang-Undang Dasar Republik Indonesia 1945.

Undang-Undang Tindak Pidana Pencurian. Kitab Undang-Undang Hukum Pidana. Kitab Undang-Undang Hukum Perdata. Sedangkan Bahan Hukum Sekunder adalah bahan hukum yang digunakan untuk mendukung bahan hukum primer, diantaranya yang berasal dari karya para ahli hukum, jurnal, data yang diperoleh dari Wilayah Hukum Kepolisian Daerah Sulawesi Barat serta buku-buku kepustakaan yang dapat dijadikan referensi untuk menunjang permasalahan penelitian ini. Dan bahan hukum tersier adalah bahan hukum yang mengandung bahan hukum sekunder yang berasal dari kamus. Teknik pengumpulan data yang digunakan adalah melakukan wawancara langsung kepada apparat Kepolisian Daerah Sulawesi Barat yang dijadikan informan. Teknik pengumpulan data dilakukan pula dengan cara membaca, menelaah secara seksama buku-buku, jurnal penelitian dan dokumen-dokumen yang relevan dengan penelitian ini. Teknik analisis data yang digunakan dalam penelitian ini adalah analisis deskriptif kualitatif. Teknik analisis ini digunakan untuk mendiskripsikan dan menjelaskan berbagai temuan yang dilakukan untuk memberikan pemahaman yang jelas menegenai hasil penelitian ini. Analisis data kualitatif ditempuh melalui reduksi data, sajian data dan penarikan kesimpulan.

\section{HASIL DAN PEMBAHASAN}

\subsection{Proses Penyidik Terhadap Anak Yang Melakukan Tindak Pidana Pencurian Di Wilayah Hukum Kepolisian Daerah Sulawesi Barat \\ Perlindungan hukum terhadap anak dalam proses} peradilan dilakukan dimulai semenjak tingkat penyelidikan, penyidikan, penuntutan, pemeriksaan di sidang Pengadilan sampai pada pelaksanaan putusan Pengadilan tersebut. Selama proses peradilan tersebut, maka hak-hak anak wajib dilindungi oleh hukum. Kesenjangan hukum dalam pelaksanaan perlindungan terhadap anak yang melakukan tindak pidana pencurian diantaranya adalah pelaksanaannya yang belum maksimal, karena kurang baiknya aparat penegak hukum dalam penanganan terhadap anak yang berkonflik dengan hukum, seperti melakukan intimidasi dan menekan anak dalam proses penyidikan. Roedjito Rubertus Kasat Reskrim Polresta Mamuju Sulawesi Barat pada tanggal 8 Juni 2021,

1. Proses penyidikan terhadap anak yang melakukan tindak pidana pencurian di Wilayah Hukum Kepolisian Daerah Sulawesi Barat, menyatakan bahwa proses penyidikan dilaksanakan tanpa pendampingan penasehat hukum maupun orang tua dari anak yang melakukan tindak pidana pencurian di Wilayah Hukum Kepolisian Daerah Sulawesi Barat. Penyidik dalam melaksanakan penyidikan terhadap anak sebagai pelaku tindak pidana pencurian, haruslah memperhatikan ketentuan Pasal 1
Angka 6 Undang Undang Nomor 11 Tahun 2012 tentang sistem peradilan pidana anak yang mengatur bahwa penyelesaian perkara tindak pidana dengan melibatkan pelaku, korban, keluarga pelaku/korban, dan pihak lain yang terkait untuk bersama-sama mencari penyelesaian yang adil dengan menekankan pemulihan kembali pada keadaan semula, dan bukan pembalasan atau dendam. Penyidik Kepolisian Daerah Sulawesi Barat, yang menangani kasus tindak Pidana Anak, harus memperlakukan anak yang melakukan tindak pidana pencurian di Wilayah Hukum Kepolisian Daerah Sulawesi Barat, dan cara yang berbeda dengan pelaku dewasa. Terkait dengan penyidikan anak tersebut haruslah dalam suasana kekeluargaan sebagaimana diatur dalam Pasal 42 Ayat (1), (2) dan (3) UndangUndang Nomor 11 tahun 2012 tentang Sistem Peradilan Anak menyebutkan bahwa penyidik wajib memeriksa tersangka dalam suasana kekeluargaan. penyidik wajib meminta pertimbangan atau saran dari pembimbing kemasyarakatan, dan apabila perlu juga dapat meminta pertimbangan atau saran dari ahli pendidikan, ahli kesehatan jiwa, ahli agama, atau petugas kemasyarakatan lainnya. Proses penyidikan terhadap anak nakal wajib dirahasiakan. Penyidikan dilakukan untuk mencari serta mengumpulkan bukti-bukti yang pada tahap pertama harus dapat memberikan keyakinan, walaupun sifatnyamasih sementara, kepada penuntut umum tentang apa yang sebenarnya terjadi atau tentang tindak pidana yang telah dilakukan oleh tersangka. Dan apabila berdasarkan keyakinan tersebut, penuntut umum berpendapat dan cukup alasannya untuk mengajukan tersangka ke Sidang Pengadilan jika masih mengulangi tindak pidana. Berdasarkan hasil wawancara dengan penyidik dalam langkah langka proses penyidikan yakni, penyidik wajib melakukan upaya paksa tindakan penyidik berupa pengekanan sementara waktu kebebasan tersangka atau terdakwa sementara waktu menurut cara waktu yang diatur dalam Uandang Undang Pasal 1 Angka 20 KUHAP Sedangkan dasar hokum melakukan penangkapan tersangka tertuaang dalam pasal 16, Pasal 17, Pasal 18 dan Pasal 19 KUHAP Undang Undang Nomor 48 Tahun 2009 Teantang kekuasaan kehakiman Pasal 7 telah menentukan bahwa, tidak seorang pun dapat dikenakan Penangkapan, Penahanan, Penggeledahan dan penyitaan selain atas perintah tertulis oleh kekuasaan yang sah.

2. Pemanggilan

Pemanggilan berdasarkan pada tinkat penyidikan diatur dalam Pasal 112, Pasal 119, dan Pasal 227 KUHAP merupakan salah satu upaya pakasa dalam fase penyidikan selain penangkapan, penahanan, penggeledahan, dan penyitaan surat, Untuk melakukan pemanggilan penyidik wajab bemberikan pemanggilan secara tertulis. Tanggal waktu surat panggilan Sengan waktu untuk menghadiri panggilan hendaknya memperhatikan tanggal waktu yang wajar yaitu paling 
lama 3 (tiga) hari sesudah diterima webelum waktu untuk dating menghadiri panggilan, Seseorang dapat dipanggil oleh penyidik untuk diperiksa dalam kapasitas selaku saksi, keterangan ahli atau tersangka, Untuk pemeriksaan selaku saksi, tidak dapat hadir dalam persidangan, maka atas saksi dapat dilakukan penyumpahan atau pengucapan janji sebelum pemeriksaan dan dibuatkan dalam berita acara, Apabila seseorang dipanggil dalam kapasitas selaku ahli (keterangan ahli) maka penyidik terlebi dahulu melakukan penyumpahan atau pengucapan janji dari keterangan ahli, bahwa yang bersangkutan akan memberikan keterangan tentang keahliannya.

3. Penggeledahan

Proses penggeledahan menurut UU No. 8 Tahun 1981 tentang Kitab Undang-undang Hukum Acara Pidana (KUHAP), penggeledahan sendiri terbagi menjadi dua, yaitu penggeledahan rumah dan penggeledahan badan. Pasal 1 angka 17 KUHAP menjelaskan Penggeledahan Rumah yaitu; Tindakan penyidik untuk memasuki rumah tempat tinggal dan tempat tertutup lainnya untuk melakukan tindakan pemeriksaan dan atau penyitaan dan atau penangkapan dalam hal dan menurut cara yang diatur dalam undang-undang ini. Penggeledahan merupakan bagian dari wewenang "penyidik" untuk memasuki dan melakukan pemeriksaan terhadap rumah seseorang atau melakukan pemeriksaan terhadap badan atau pakaian seseorang yang dibenarkan oleh undangundang. Tindakan penyidik tidak hanya terbatas pada melakukan pemeriksaan akan tetapi bisa sekaligus melakukan penangkapan dan penyitaan sepanjang telah memenuhi ketentuan hukum acara yang mengatur,

4. Penangkapan

Dalam proses penagkapan menurut Pasal 1 angka 20 KUHAP merupakan "Suatu tindakan penyidik berupa pengekangan sementara waktu kebebasan tersangka atau terdakwa apabila terdapat cukup bukti guna kepentingan penyidikan atau penuntutan dan atau peradilan. Selanjutnya mengenai masa waktu penangkapan menurut Pasal 19 ayat (1) bahwa jangka penangkapan tidak boleh lebih dari satu hari. Artinya apabila selama 1×24 jam pemeriksaan tersangka tidak memenuhi syarat untuk ditingkatkan statusnya sebagai tahanan maka ia harus dibebaskan demi hukum, bagian dari bentuk upaya paksa yang diatur dalam KUHAP yang pelaksanaannya diberikan batasan yang bersifat mencegah agar pelaksanaannya tidak mengesampingkan hak asasi manusia,

5. Penyitaan

Salah satu tugas dan wewenang yang diberikan UU No. 8 Tahun 1981 tentang Kitab Undang-undang Hukum Acara Pidana (KUHAP) kepada Polisi Republik Indonesia (POLRI) untuk melakukan penyitaan terhadap benda atau alat yang mempunyai keterkaitan dengan tindak pidana yang dilakukan Tersangka. Kemudian oleh penyidik diserakan ke Jaksa untuk digunakan sebagai barang bukti dalam proses pembuktian di persidangan. Penyitaan dalam Kitab Undang-undang Hukum Acara Pidana (KUHAP) diatur secara terpisah dalam beberapa bagian, sebagian besar diatur dalam Bab V bagian ke 4 (empat) Pasal 38 sampai dengan Pasal 48 KUHAP dan
Pasal 128 sampai 130 KUHAP serta sebagian kecil diatur pula dalam Pasal 1 butir 16 KUHAP. Dalam Pasal 1 butir 16 KUHAP, menjelaskan definisinya yakni, Penyitaan adalah serangkaian tindakan penyidik untuk mengambil alih dan atau menyimpan di bawah penguasaan benda bergerak, berwujud atau tidak berwujud untuk kepentingan pembuktian dalam penyidikan, penuntutan dan pemeriksaan dipengadilan,

6. Penahanan

Penahanan adalah penempatan tersangka atau terdakwa ditempat tertentu oleh penyidik atau penuntut umum atau hakim dengan penetapannya dalam hal serta menurut cara yang diatur dalam KUHAP. Penahanan Lanjutan adalah penahanan yang dilakukan terhadap tersangka atau terdakwa yang telah ditahan namun karena sesuatu hal tidak menyelesaikan seluruh waktu yang telah ditetapkan (karena melarikan diri, karena dikeluarkan, karena tahanannya dibantarkan atau karena penahanannya ditangguhkan). Pembantaran Penahanan adalah dilakukan terhadap tersangka atau terdakwa yang ditahan, namun karena sakit dan perlu dirawat dirawat inap dirumah sakit maka penahanannya dibantarkan, artinya selama yang bersangkutan menjalani rawat inap maka waktu penahanan tidak dihitung. Kewenangan penyidikan pada hakikatnya merupakan bagian juga dari kewenangan pemidanaan, Sebagai negara hukum Negara Indonesia selalu berupaya untuk memenuhi persyaratanpersyaratan agar menjadi negara yang menjunjung tinggi hukum yang sebenar-benarnya. Sebagai bukti dari pernyataan ini adalah dianutnya asas legalitas dalam Pasal 1 ayat (1) Kitab Undang-Undang Hukum Pidana yang berbunyi: "Tiada suatu perbuatan yang dapat dipidana, kecuali atas kekuatan aturan pidana dalam perundang-undangan yang telah ada sebelum perbuatan dilakukan". Kewenangan dalam hal melakukan penahanan terhadap tersangka atau terdakwa yaitu Penyidik atau penyidik pembantu, berwenang melakukan penahanan untuk kepentingan penyidikan, Penuntut umum, berwenang melakukan penahanan atau penahanan lanjutan untuk kepentingan penuntutan dan Hakim, berwenang untuk melakukan penahanan melalui penetapannya untuk kepentingan pemeriksaan hakim di sidang pengadilan. Pada saat penahanan itu akan dilaksanakan, maka surat perintah penahanan dan penahanan lanjutan tersebut harus diserahkan kepada tersangka atau terdakwa dan kepada keluarganya setelah penahanan dilaksanakan (sebagai tembusan). Surat perintah / penetapan penahanan berisikan yaitu Identitas dari tersangka atau terdakwa (nama lengkap, umur, pekerjaan, agama, dan alamat tinggal), Alasan penahanan, Uraian singkat perkara kejahatan yang dipersangkakan atau didakwakan, dan Tempat dimana tersangka atau terdakwa ditahan,

Beradasarkan pasal 110 Angka 1 KUHAP "Dalam hal penyidik telah selesai melakukan penyidikan, penyidik wajib segera menyerahkan berkas perkara itu kepada penuntut umum." Adapun isi berkas perkara diantaranya resume hasil penydikan (kesimpulan penyidik), laporan polisi, surat perintah (surat perintah penyidikan, surat pemberitahuan dimulainya penyidikan, surat panggilan, berita acara pemeriksaan saksi, ahli, dan tersangka, surat perintah 
penangkapan, surat perintah penahanan, surat perintah penyitaan, surat perintah penggeledahan, berita acara pemeriksaan TKP, daftar saksi, daftar tersangka, dan daftar barang bukti.

Selanjutnya apabila berkas perkara telah dinyatakan lengkap (P-21) oleh jaksa penuntut umum maka penyidik harus segera menyerahkan tersangka dan barang bukti ke jaksa penuntut umum untuk selanjutnya dilakukan penuntutan. Menurut penulis bahwa penyidikan adalah suatu pekerjaan yang dilakukan untuk membuat jelas suatu perkara, yang selanjutnya dapat dipakai oleh penuntut umum sebagai dasar untuk mengajukan tersangka beserta bukti-bukti yang ada. Jika dicermati pekerjaan penyidikan mempunyai segi-segi yuridis, disebabkan karena keseluruhan pekerjaan tersebut ditujukan pada pengadilan. Penyidikan Perkara Anak yang dilaksanakan oleh Penyidik Anak di Wilayah Hukum Kepolisian Daerah Sulawesi Barat dilaksanakan dalam suasana kekeluargaan. Disisi lain, dalam melakukan penyidikan anak, penyidik wajib meminta pertimbangan atau saran dari pembimbing kemasyarakatan atau jika perlu kepada ahli pendidikan, psikolog, psikiater, tokoh agama, pekerja sosial dan tenaga ahli lainnya. yang berada di Mamuju. Penyidik wajib mengupayakan Diversi dalam waktu paling lama 7 (tujuh) hari setelah penyidikan dimulai. Jika proses Diversi berhasil mencapai kesepakatan, Penyidik menyampaikan berita acara Diversi beserta Kesepakatan Diversi kepada ketua pengadilan negeri untuk dibuat penetapan. Jika proses Diversi gagal, Penyidik wajib melanjutkan penyidikan dan melimpahkan perkara ke Penuntut Umum dengan melampirkan berita acara Diversi dan laporan penelitian kemasyarakatan. Penyidik anak merupakan penyidik yang ditetapkan berdasarkan keputusan Kepala Kepolisian Negara Republik Indonesia atau pejabat lain yang ditunjuk, yang memenuhi syarat untuk ditetapkan sebagai Penyidik Anak sesuai Pasal 26 Ayat (3) Undang-Undang Nomor 11 Tahun 2012 yaitu penyidik yang telah berpengalaman sebagai penyidik. Mempunyai tentang peradilan Anak. Peranan penyidik dalam penyidikan tindak pidana pencurian yang dilakukan oleh anak di Wilayah Hukum Kepolisian Daerah Sulawesi Barat termasuk dalam peranan normatif dan faktual. Peran normatif dilaksanakan dengan peraturan perundang-undangan, khususnya UndangUndang Nomor 2 Tahun 2002 tentang Kepolisian Negara Republik Indonesia dan Undang-Undang Nomor 11 Tahun 2012 tentang Sistem Peradilan Pidana Anak. Peranan faktual dilaksanakan berdasarkan fakta mengenai adanya anak yang melakukan tindak pidana pencurian dengan cara menyediakan penyidik khusus anak, melaksanakan penyidikan di ruang pemeriksaan khusus anak, melaksanakan penyidikan dengan suasana kekeluargaan, meminta laporan penelitian kemasyarakatan, melaksanakan upaya paksa dengan berpedoman pada Undang-Undang Sistem Peradilan Anak, minat, perhatian, dedikasi, dan memahami masalah anak dan telah mengikuti pelatihan teknis. Peradilan Pidana Anak terdiri atas Pidana Peringatan menurut Pasal 71 Undangundang No. 11 tahun 2012 dapat diketahui bahwa pidana perigatan merupakan pidana ringan yang tidak mengakibatkan pembatasan kebebasan anak. Penjelasan Pasal 9 ayat (2) huruf b Undang-Undang No.11 tahun 2012 Tentang Sistem Peradilan Pidana Anak menyebutkan bahwa yang dimaksud dengan "pidana ringan" adalah pidana penjara atau pidana kurungan paling lama 3 (tiga) bulan. Dalam Pasal 73 Ayat (1). Ayat (2). Ayat (3). Ayat (4) UU No. 11 Tahun 2012, dapat diketeahui bahwa pidana dengan syarat adalah pidana dijatuhkan oleh hakim kepada anak yang tidak perlu dilaksanakan asal selama menjalani masa pidana, memenuhi syarat umum berupa tidak akan melakukan tindak pidana dan syarat khusus berupa untuk melakukan atau tidak melakukan hak tertentu yang ditetapkan dalam putusan hakim. Pembinaan di luar lembaga yaitu mengikuti program pembimbingan dan penyuluhan yang dilakukan oleh pejabat Pembina. Mengikuti terapi dirumah sakit jiwa, Mengikuti terapi akibat penyalahgunaan alkohol, narkoba, psikotropika, dan zat adiktif lainnya. Pidana pelayanan masyarakat merupakan pidana yang dimaksudkan untuk mendidik anak dengan meningkatkan kepeduliannya pada kegiatan ke masyarakat yang positif. Pada penjelasan Pasal 77 Ayat (1) UU No. 11 Tahun 2012 menyebutkan bahwa yang dimaksud dengan "pidana pengawasan" adalah pidana yang khusus dikenakan untuk anak, yakni pengawasan yang dilakukan oleh penuntut umum terhadap perilaku anak dalam kehidupan sehari-hari di rumah anak dan pemberian bimbingan yang dilakukan oleh pembimbing kemasyarakatan. Pidana pengawasan yang dapat dijatuhkan kepada anak sebagaimana dimaksud dalam Pasal 71 Ayat (1) huruf b Angka 3 paling singkat 3 (tiga) bulan dan paling lama 2 (dua) tahun. Pelatihan kerja sebagaimana Penjelasan Pasal 78 Ayat (1) UU No. 11 Tahun 2012 menyebutkan bahwa yang dimaksud dengan "lembaga yang melaksanakan peatihan kerja" antara lain balai latihan kerja, lembaga pendidikan vokasi yang dilaksanakan, misalnya oleh Kementrian yang menyelenggarakan urusan pemerintahan di bidang ketenagakerjaan, pendidikan, atau sosial. Dan Pembinaan dalam lembaga dilakukan di tempat pelatihan kerja atau lembaga pembinaan yang diselenggarakan, baik oleh pemerintah maupun swasta. Pidana pembinaan dalam lembaga dijatuhkan apabila keadaan dan pernbuatan anak tidak membahayakan masyarakat. Pidana penjara pada pasal 79 Ayat (1) UU No. 11 Tahun 2012 disebut pidana pembatasan kebebasan diberlakukan dalam hal anak melakukan tindak pidana berat atau pidana yang disertai dengan kekerasan. Pidana pembatasan kebebasan yang dijatuhkan terhadap anak paling lama $1 / 2$ (satu perdua) dari maksimum pidana penjara yang diancamkan terhadap orang dewasa. Dalam hal ini yang dimaksud dengan "maksimum ancman pidana bagi orang dewasa" dalam penjelasan 79 Ayat (2) tersebut menyebutkan adalah maksimum ancaman pidana penjara terhadap tindak pidana yang dilakukan sesuai dengan ketentuan dalam KUHP atau Undang-Undang lain. Adapun minimum khusus pidana penjara tidak berlaku terhadap anak. Pidana Tambahan terdiri atas perampasan keuntungan yang diperoleh dari tindak pidana atau pemenuhan kewajiban adat. Penjelasan Pasal 71 Ayat (1) huruf b UU No. 11 Tahun 2012 menyerbutkan bahwa yang dimaksud dengan "kewajiban adat" adalah denda atau tindakan yang harus dipenuhi berdasarkan norma adat setempat yang tetap menghormati harkat dan martabat anak serta tidak membahayakan kesehatan fisik dan mental anak. Jenis-jenis dari tindakan yang dapat dikenakan kepada anak menurut Pasal 82 Ayat (1) UU No. 11 Tahun 2012 tentang Sistem Peradilan Anak yaitu: Pengembalian kepada orang tua atau wali. Penyerahan kepada seseorang atau penyerahan kepada seseorang yaitu penyerahan kepada orang dewasa yang dinilai cakap, berkelakuan baik, dan bertanggung jawab oleh hakim serta dipercaya oleh anak. Perawatan di rumah sakit jiwa. Perawatan di Lembaga Penyelenggaraan Kesejahteraan Sosial (LPKS). Kewajiban mengikuti pendidikan formal dan/atau pelatihan yang diadakan oleh pemerintah atau badan swasta. Pencabutan surat izin mengemudi ; dan/atau Perbaikan akibat 
tindak pidana. Dalam penerapan sanksi terhadap anak, maka terdapat beberapa teori yang dapat digunakan sebagai landasan dalam penerapan sanksi pidana yakni Teori imbalan (absolutelvergeldingstheorie). Menurut teori ini dasar dari pemberian hukuman harus dicari dari kejahatan itu sendiri. Dimana karena kejahatan itu telah memberi dan menimbulkan penderitaan dari orang lain maka sebagai imbalannya (vergelding) maka si pelaku juga harus diberi penderitaan. Teori maksud atau tujuan (relativeldoeltheorie), teori ini menunjukkan bahwa hukuman dijatuhkan untuk melaksanakan maksud atau tujuan dari hukuman itu. Dimana dalam teori ini tujuan hukuman adalah untuk mencegah (prevensi) kejahatan. Dimana terdapat perbedaan dalam prevensi yakni Prevensi umum (algemene preventive) hal ini dapat dilakukan dengan ancaman hukuman, penjatuhan hukuman, dan pelaksanaan hukuman. Spesial prevensi, yakni yang ditujukan kepada orang yang melakukan kejahatan itu. Teori gabungan (verenigingstheorie) Pada dasarnya teori gabungan ini adalah gabungan antara teori imbalan dan teori maksud dan tujuan. Dimana apabila digabungkan maka pengertian teori gabungan ini adalah mengajarkan bahwa penjatuhan hukuman adalah untuk mempertahankan tata tertib hukum dalam masyarakat dan untuk memperbaiki pribadi si penjahat. Hukum pidana modern menyatakan bahwa pemidanaan yang diterima oleh seorang anak yang melakukan perbuatan itu tidak hanya berupa pidana, akan tetapi juga tindakan yang bertujuan untuk melindungi masyarakat dari perbuatan-perbuatan yang merugikannya yang sering disebut dengan double track system, namun dilihat dari latar belakang kemunculan dapat disimpulkan bahwa ide dasar sistem tersebut adalah kesetaraan antara sanksi pidana dan sanksi tindakan. Sistem peradilan pidana (criminal justice system) adalah "sistem dalam suatu masyarakat untuk menanggulangi masalah kejahatan". Berdasarkan dengan istilah sistem peradilan pidana atau criminal justice system tidak terpisah dari istilah sistem "the word system conveys an impression of a complex to end" artinya bahwa kata sistem menunjukkan adanya suatu kesan dari objek yang komplek lainnya dan berjalan dari awal sampai akhir, oleh karena itu dalam mewujudkan tujuan sistem tersebut ada empat instansi yang terkait yaitu kepolisian, kejaksaan, pengadilan dan lembaga pemasyarakatan. Keempat komponen tersebut harus bekerja sama secara terpadu (integrated criminal justice administration). Berproses secara terpadu artinya bahwa keempat sub sistem ini bekerja sama berhubungan walaupun masing-masing berdiri sendiri. Polisi selaku penyidik melakukan penyidikan termasuk penyelidikan, penangkapan, penahanan, penggeledahan, penyitaan dan pemeriksaan surat. Jaksa selaku penuntut umum melakukan penuntutan berdasarkan hasil penyidikan yang disampaikan oleh penyidik. Hakim atas dasar dakwaan penuntut umum melakukan pemeriksaan dalam sidang pengadilan. Dalam hal penjatuhan sanksi pidana pada anak yang berhadapan dengan hukum, ternyata terdapat beberapa aspek yang perlu diperhatikan dalam penjatuhan sanksi pidana anak. Hal ini mengandung maksud bahwa dalam hal penjatuhan sanksi pidana anak, walaupun substansi dan pemenuhan unsur sama dengan orang dewasa namun pengenaan sanksi pidana anak tidak sama dengan orang dewasa. Pembentukan peraturan perundang-undangan adalah proses pembuatan peraturan perundang-undangan yang pada dasarnya dimulai dari perencanaan, persiapan, teknik penyusunan, perumusan, pembahasan, pengesahan, pengundangan dan penyebarluasan. Di antara rangkaian proses di atas ada proses yang tidak disebutkan secara tegas tetapi mempunyai peran yang sangat penting yaitu proses pengharmonisasian. Pengharmonisasian merupakan salah satu rangkaian proses pembentukan peraturan perundang-undangan. Proses pengharmonisasian dimaksudkan agar tidak terjadi atau mengurangi tumpang tindih peraturan perundang-undangan. Berkaitan dengan perumusan suatu norma atau peraturan perundangundangan maka dalam hal ini norma hukum ditetapkan oleh badan hukum yang berwenang. Sistem peradilan pidana anak (juvenile justice system) adalah segala unsur sistem peradilan pidana yang terkait di dalam penanganan anak yang bermasalah dengan hukum. Polisi sebagai institusi formal ketika anak nakal pertama kali bersentuhan dengan sistem peradilan, yang juga akan menentukan apakah anak akan dibebaskan atau diproses lebih lanjut. Jaksa dan lembaga pembebasan bersyarat yang juga akan menentukan apakah anak akan dibebaskan atau diproses ke pengadilan anak. Pengadilan anak, tahapan ketika anak akan ditempatkan dalam pilihanpilihan, mulai dari dibebaskan sampai dimasukkan dalam institusi penghukuman dan terakhir institusi penghukuman. Proses peradilan anak yang berhadapan dengan hukum maka sebelum membahas mengenai hal bagaimana proses peradilan anak di Kabupaten Mamuju, maka hendaknya kita membahas mengenai apa sebenarnya yang dimaksud dengan proses penanganan anak itu sendiri. Proses peradilan adalah suatu proses yuridis, dimana harus ada kesempatan orang berdiskusi dan dapat memperjuangkan pendirian tertentu yaitu mengemukakan kepentingan oleh berbagai macam pihak, mempertimbangkannya dan dimana keputusan yang diambil tersebut mempunyai motivasi tertentu. Seperti halnya orang dewasa, anak sebagai pelaku tindak pidana juga akan mengalami proses hukum yang identik dengan orang dewasa yang melakukan tindak pidana, arti kata identik di sini mengandung arti "hampir sama", yang berbeda hanya lama serta cara penanganannya. Menghadapi dan menangani proses peradilan anak yang melakukan tindak pidana pencurian, maka hal yang pertama yang tidak boleh dilupakan adalah melihat kedudukannya sebagai anak dengan semua sifat dan ciri-cirinya yang khusus, dengan demikian orientasi adalah bertolak dari konsep perlindungan terhadap anak dalam proses penanganannya sehingga hal ini akan akan berpijak ada konsep kesejahteraan anak dan kepentingan anak tersebut. Penanganan anak dalam proses hukumnya memerlukan pendekatan, pelayanan, perlakuan, perawatan serta perlindungan yang khusus bagi anak dalam upaya memberikan perlindungan hukum terhadap anak yang berhadapan dengan hukum. Perlindungan anak merupakan suatu bidang pembangunan nasional, melindungi anak adalah melindungi manusia, dan membangun manusia seutuh mungkin. Hakekat pembangunan nasional adalah pembangunan manusia Indonesia seutuhnya yang berbudi luhur. Mengabaikan masalah perlindungan anak berarti tidak akan memantapkan pembangunan nasional. Akibat tidak adanya perlindungan anak akan menimbulkan berbagai permasalahan sosial yang dapat mengganggu penegakan hukum, ketertiban, keamanan, dan pembangunan nasional. Maka, ini berarti bahwa perlindungan anak harus diusahakan apabila kita ingin mengusahakan pembangunan nasional yang memuaskan. 


\subsection{Faktor Penghambat Dalam Proses Penyidikan} Terhadap Anak Yang Melakukan Tindak Pidana Pencurian di Wilayah Hukum Kepolisian Daerah

\section{Sulawesi Barat}

Pelaksanaan proses penyidikan yang dilakukan oleh penyidik tidak selamanya berjalan dengan baik, karena terkadang penyidik dalam melakukan proses penyidikan mendapatkan hambatan-hambatan dalam proses pelaksanaannya. Begitu juga halnya yang terjadi dalam pelaksanaan penyidikan yang dilakukan penyidik terhadap kasus pencurain yang dilakukan oleh anak di Wilayah Kepolisian Daerah Sulawesi Barat yang dilakukan oleh anak dibawah umur juga mendapatkan hambatan-hambatan dalam pelaksanaan penyidikannya.

Status sosial seseorang di dalam masyarakat banyak dipengaruhi oleh beberapa faktor. Selama di dalam masyarakat ada sesuatu yang dihargai maka selama itu pula ada pelapisan-pelapisan di dalamnya dan pelapisan-pelapisan itulah Untuk masyarakat Kabupaten Mamuju status sosial seseorang ditentukan oleh banyak faktor diantaranya ekonomi, pendidikan, lingkungan, dan lain-lain sebagainya. Begitupula status sosial ini ditentukan oleh stratifikasi sosial yang beraspek vertikal di bidang ekonomi, dimana adanya ketidak beresan antara orang kaya dengan orang miskin sehingga membuat orang kaya menduduki kelasnya sendiri tanpa memperhatikan lingkungan sekitarnya sehingga oarang miskin berada pada kelasnya sendiri yang hidupnya tambah melarat.

Berdasarkan hasil wawancara penulis dengan Muh. Sulaiman, Kasubnit 1 Unit PPA Polresta Mamuju Sulawesi Barat pada tanggal 15 Juni 2021 mengemukakan bahwa faktor-faktor yang menghambat dalam proses penyidikan di Kabupaten Mamuju Adapun hambatan-hambatan yang ditemui penyidik dalam menjalankan proses penyidikan terhadap anak yang melakukan pencurian diwilayah Hukum Kepolisian Daerah Sulawesi Barat yang dilakukan oleh anak dibawah umur yaitu:

1. Kurangnya Personil PPA Yang Menangani Perkara Masalah Anak

Berdasarkan Peraturan Kepala Kepolisian Negara Republik Indonesia Nomor 2 Tahun 2021 tentang struktur organisasi satuan reserse krimial pada Polresta Mamuju Wilayah Hukum Kepolisian Daerah Sulawesi Barat. khususnya pada unit PPA (perlindungan perempuan dan anak) yang seharusnya dalam DSPP (daftar susunan porsonil polri) sejumlah 20 (dua puluh) personil yang seharusnya mengawaki unit PPA (perlindungan perempuan dan anak) tetapi secara rill (nyata) yang bertugas pada unit PPA sejumlah 5 (lima) Personil

Hal itu kurangnya jumlah personil yang tidak sesuai dengan DSPP dan belum semua personil pada unit PPA mengikuti pendidikan pengembangan / pelatihan khusus untuk penyidik tindak anak, sehingga penanganan laporan tindak pidana yang dilakukan oleh anak penanganannya sangat menyita waktu dan tidak dapat dilaksanakan secara optimal

2. Tidak Adanya Tempat Penanahan Khusus Untuk Anak Untuk kepentingan penyidikan maka menurut Pasal 31 UndangUndang Nomor 11 Tahun 2012 Tentang sissim peradilan anak, bahwa penyidik berwenang melakukan penahanan terhadap anak yang diduga keras melakukan tindak pidana berdasarkan bukti permulaan yang cukup,
Menurut Pasal 32 Undang-Undang Nomor 11 Tahun 2012 tentang system peradilan pidana anak, ada dua alasan penahanan terhadap para pelaku pidana yang masih di bawah umur, yaitu; Untuk kepentingan anak dan untuk kepentingan masyarakat

Kedua alasan tersebut harus dinyatakan secara tegas dalam surat perintah penahanan. Pada dasarnya penahanan dilakukan untuk kepentingan pemeriksaaan, dantempat tahanan anak harus dipisahkan dari tempat tahanan orang dewasa.

3. Lamanya Penelitian Dari Bada Pemasyarakatan (BAPAS)

Dalam proses penyidikan terhadap tindak pidana pelemparan Mapolresta Pekanbaru yang dilakukan oleh anak, pihak penyidik dari Mapolresta Pekanbaru selain menggunakan KUHAP sebagai acuan dalam penyidikan juga menggunakan Undang-Undang Nomor 11 Tahun 2012 Tentang sistim peradilan pidana anak. Sehingga dalam melakukan penyidikan para penyidik meminta kepada Badan Pemasyarakatan untuk melakukan penelitian terhadap anak tersebut sebagai pelaku. Sesuai dengan yang diamanatkan dalam Undang-Undang Nomor 11 Tahun 2012 Tentang sistim peradilan pidana anak Pasal 27 ayat (1) yaitu

Dalam melakukan pemyidikan terhadap anak nakal, penyidik wajib meminta pertimbangan atau saran dari Pembimbing Kemasyarakatan, dan apabila perlu juga dapat meminta pertimbangan atau saran dari ahli pendidikan, ahli kesehatan jiwa, ahli agama, atau petugas kemasyarakatan lainnya". Badan Pemasyarakatan (BAPAS) dalam melakukan penelitian terhadap anak sebagai pelaku tindak pidana bertugas membantu memperlancar tugas penyidik, penuntut umum, dan hakim dalam perkara anak nakal, baik di dalam maupun di luar sidang anak.18 Adapun petugas kemasyarakatan terdiri dari

a. Pembimbing Kemasyarakatan dari Departemen Kehakiman

b. Pekerja Sosial dari Departemen Sosial

c. Pekerja Sosial Sukarela dari Organisasi Sosial Kemasyarakatan

\section{KESIMPULAN DAN SARAN}

Hasil penelitian dan pembahasan dapat disimpulkan bahwa proses penyidikan terhadap anak penyedik melakukan pemanggilan, penagkapan, penggeledahan badan/ rumah, penyitaan barang bukti, penahanan dan melakukan pemberkasan terhadap kasus yang ditanganinya di samping itu penyidikan terhadap anak yang melakukan tindak pidana pencurian di Wilayah Hukum Kepolisian Daerah Sulawesi Barat yaitu dilaksanakan dalam suasana kekeluargaan terhadap anak yang melakukan proses penyidikan, penyidik wajib meminta pertimbangan atau saran dari pembimbing kemasyarakatan atau jika perlu kepada ahli pendidikan, psikolog, psikiater, tokoh agama, pekerja sosial dan tenaga ahli lainnya yang ada di Kota Mamuju. Faktor penghambat dalam proses penyidikan terhadap anak yang melakukan tindak pidana pencurian di Wilaya Hukum Kepolisian Daerah Sulawesi Barat yaitu sarana dan prasarana kurang memadai. kurangnya penyidik yang sudah mengikuti pelatihan khusus tindak pidana yang dilakukan oleh anak, tidak adanya tempat penahanan kahusus untuk anak serta lambatnya surat penelitian dari BAPAS (Balai Pemasyarakatan) Dan terkadang 
anak tidak memiliki bukti lahir berupa akte kelahiran atau kartukeluarga

\section{DAFTAR PUSTAKA}

Amiruddin, Korupsi Dalam Pengadaan Barang Dan Jasa, Cet.1, Genta Publishing, 2010, Yogyakarta

Andi Hamzah, Pengantar Hukum Acara Pidana, Liberty, Yogyakarta, 1996

Bismar Siregar, Bunga Rampai Karangan Tersebar Bismar Siregar, (Jakarta : CV. Rajawali, 1989)

Evi Hartanti, Tindak Pidana Korupsi, Cet. Ke.5, Edisi Kedua, Sinar Grafika, 2014, Jakarta

Ferdi Wp. Pembiayaan Pendidikan: Suatu Kajian Teoritis Financing Of Education: A Theoritical Study. Jurnal Pendidikan Dan Kebudayaan. 2013; 19(4).

Gunarto MP. Asas Keseimbangan Dalam Konsep Rancangan Undang-Undang Kitab Undang-Undang Hukum Pidana. Mimbar Hukum. 2012; 24(1).

Hamzah Hatrik, Asas Pertanggungjawaban Korporasi Dalam Hukum Pidana Indonesia, Raja Grafindo, Jakarta, 1996

Harum Pudjiarto, Politik Hukum Undang-Undang Pemberantasan Tindak Pidana Korupsi di Indonesia, (Yogyakarta: Universitas Atma Jaya, 1994)

Herawati Y. Konsep Keadilan Sosial Dalam Bingkai Sila Kelima Pancasila. Jurnal Upn Veteran Yogyakarta. 2014; 18(1).

Irfani. Tindak Pidana Korupsi Sebagai Kejahatan Luar Biasa. Lambung Mangkurat Law Journal. 2017; 9(3).

Johny Ibrahim, Teori dan Metodelogi dalam Penelitian Hukum Normatif, Bayumedia Publishing, 2008, hlm. 34

Khairi M. Partisipasi Masyarakat Dalam Upaya Penegakan Hukum Peraturan Daerahpersepektif Teori Negara Hukum. Jurnal Selisik. 2017; 3(5).

Marwan Mas,Pemberantasan Tindak Pidana Korupsi ,Ghalia Indonesia,Bogor,2014,hlm. 209

Moeljatno, Asas-Asas Hukum Pidana, Rineka Cipta, Jakarta, 1993

Mudakir Iskandar Syah, Pengantar Ilmu Hukum dan Tata Hukum Indonesia, ( Jakarta : Sagung Seto, 2008)

Murtir Jeddawi, Negara Hukum, Good Governance, dan Korupsi di Daerah, (Yogyakarta: Total Media, 2011)

Peter Mahmud Marzuki, Penelitian Hukum, Kencana, 2011, hlm. 35

Pradana HA. Tindak Pidana Korupsi Dalam Pemberian Dana Hibah. Jurist-Diction. 2020; 3(1).

Pusat bahasa Indonesia Departemen Pendidikan Nasional, Edisi Keempat Tahun 2008

Ridlwan Z. Negara Hukum Indonesia Kebalikan Nachtacherstaat. Fiat Justicia Jurnal Ilmu Hukum. 2012; 5(2).

Rudi Pardede, Proses Pengembalian Kerugian Negara Akibat Korupsi, (Yogyakarta : Genta publishing,2016)

Seno Aji, Hukum-Hukum Pidana, Erlangga, Jakarta, 1984

Setiadi E. Penegakan Hukum Pidana Terhadap Kasus-Kasus Korupsi Dalam Menciptakan Clean Government. Mimbar Hukum. 2000; 4.

Sudarto, Hukum dan Hukum Pidana, Cet 4. Alumni, Bandung, 1986

Syahriah R. Efektivitas Penanganan Kasus Korupsi Oleh Kepolisian (Studi Pada Unit Tipikor Polres Polman). Ojs Univervitas Negeri Makassar. 2017.
Undang Undang No. 8 Tahun 1981 Tentang : Kitab Undang Undang Hukum Acara Pidana

Undang-Undang No. 28 Tahun 1999 tentang Penyelenggaraan Negara yang Bersih dan Bebas dari Korupsi

Undang-Undang No.: 17 tahun 2003 tentang Keuangan Negara (UUKN)

Undang-Undang Nomor 15 Tahun 2006 tentang Badan Pemeriksa Keuangan (BPK)

Undang-undang Nomor 20 Tahun 2001 tentang Tindak Pidana Korupsi

Undang-Undang Nomor $31 \quad$ Tahun $1999 \quad$ Tentang Pemberantasan Tindak Pidana Korupsi

Undang-Undang Republik Indonesia Nomor 20 Tahun 2001 Tentang Perubahan Atas Undang-Undang Nomor 31 Tahun 1999 Tentang Pemberantasan Tindak Pidana Korupsi. 